\title{
BACTERIAL DIVERSITY CHARACTERIZATION IN PETROLEUM SAMPLES FROM BRAZILIAN RESERVOIRS
}

\author{
Valéria Maia de Oliveira ${ }^{1 *}$; Lara Durães Sette ${ }^{1}$; Karen Christina Marques Simioni' ${ }^{1}$ Eugênio Vaz dos Santos Neto ${ }^{2}$ \\ ${ }^{1}$ Centro Pluridisciplinar de Pesquisas Químicas, Biológicas e Agrícolas, Universidade Estadual de Campinas, Campinas, SP, \\ Brasil; ${ }^{2}$ Petrobras R\&D Center, Rio de Janeiro, RJ, Brasil.
}

Submitted: August 16, 2007; Returned to authors for corrections: November 22, 2007; Approved: July 14, 2008.

\begin{abstract}
This study aimed at evaluating potential differences among the bacterial communities from formation water and oil samples originated from biodegraded and non-biodegraded Brazilian petroleum reservoirs by using a PCR-DGGE based approach. Environmental DNA was isolated and used in PCR reactions with bacterial primers, followed by separation of $16 \mathrm{~S}$ rDNA fragments in the DGGE. PCR products were also cloned and sequenced, aiming at the taxonomic affiliation of the community members. The fingerprints obtained allowed the direct comparison among the bacterial communities from oil samples presenting distinct degrees of biodegradation, as well as between the communities of formation water and oil sample from the nonbiodegraded reservoir. Very similar DGGE band profiles were observed for all samples, and the diversity of the predominant bacterial phylotypes was shown to be low. Cloning and sequencing results revealed major differences between formation water and oil samples from the non-biodegraded reservoir. Bacillus sp. and Halanaerobium sp. were shown to be the predominant components of the bacterial community from the formation water sample, whereas the oil sample also included Alicyclobacillus acidoterrestris, Rhodococcus sp., Streptomyces sp. and Acidithiobacillus ferrooxidans. The PCR-DGGE technique, combined with cloning and sequencing of PCR products, revealed the presence of taxonomic groups not found previously in these samples when using cultivation-based methods and 16S rRNA gene library assembly, confirming the need of a polyphasic study in order to improve the knowledge of the extent of microbial diversity in such extreme environments.
\end{abstract}

Key-words: bacterial diversity, community DNA, cultivation-independent analysis, petroleum, 16S rDNA.

\section{INTRODUCTION}

Accumulations of biodegraded oils are abundant and have been a problem for petroleum production since the beginning of commercial oil production. This is due to the action of microorganisms that destroy hydrocarbons and other components to produce altered, denser "heavy oils". The presence and role of microorganisms in deep subsurface environments have been first addressed by Bastin (3), who performed an extensive microbiological study describing the widespread presence of sulphate-reducing bacteria in oilproducing wells. Since that time, observations have corroborated the existence of large and diverse populations of microbes with different metabolic activities in petroleum systems $(20,41)$.

Although these studies have led to the description of an increasing number of new species in deep oil reservoirs $(7,11,18$, $33)$, relatively little information is available on the composition of microbial assemblages in these subsurface environments. This is particularly due to the non-culturability conundrum (24), which preclude traditional microbiological techniques based on cultivation from being adequate as the sole basis for the monitoring of bacterial communities, especially the ones associated to extreme environments (14). Direct environmental DNA-based molecular techniques are the methods of choice to

*Corresponding Author. Mailing address: Centro Pluridisciplinar de Pesquisas Químicas, Biológicas e Agrícolas - CPQBA/UNICAMP, CP 6171, CEP 13081-970, Campinas, SP, Brasil. Phone: +55 (19) 3884-7500 ext. 263 / Fax: +55 (19) 3884-7811. E-mail: vmaia@cpqba.unicamp.br 
overcome the limitations of the culture-dependent approaches and characterize complex microbial assemblages in environmental samples $(14,40)$. For instance, the analysis of 16S ribosomal DNA sequences recovered directly from environmental samples can be highly informative $(8,36)$. In addition, denaturing gradient gel electrophoresis (DGGE) of PCR-amplified DNA fragments may offer a rapid means for the study of bacterial populations in environmental samples, either at a gross taxonomic level (22), or at more refined levels (31). Despite the recent use of molecular techniques for a broader survey of microbial communities in oil fields, our knowledge of the nature and diversity of bacteria growing in these ecosystems is still scarce, and their metabolic activities in situ largely ignored. Furthermore, most studies have revealed microbial assemblages present in formation or injection water samples obtained from production wells $(4,23,42)$, with very few data being reported about oil samples $(32,37)$.

The goal of this study was to rapidly evaluate the bacterial diversity in formation water and oil samples with different degrees of biodegradation by using a PCR-DGGE based approach, a fast and low cost molecular tool commonly used for microbial community analysis. Additionally, a preliminary characterization of the bacterial community composition was carried out by cloning and sequencing $16 \mathrm{~S}$ rDNA fragments amplified from oil and water samples.

\section{MATERIALS AND METHODS}

\section{Sampling}

Formation water (water filling the pores and fractures of rocks) and oil samples were collected in May of 2002, at a production petroleum platform, in the Campos Basin (Brazil). The oil samples used in this study are representative examples of one nonbiodegraded oil produced from the coquina sequence of the Lagoa Feia Formation (3,070-3,240 m deep, reservoir temperature about $85^{\circ} \mathrm{C} ; 30^{\circ} \mathrm{API},{ }^{\circ} \mathrm{API}=\left(141.5 / \mathrm{oil}\right.$ density $\left.@ 15.6^{\circ} \mathrm{C}\right)-131.5$, named reservoir one), one biodegraded oil produced from sandstones of the Carapebus Formation (1,885-1,903 m, reservoir temperature about $62^{\circ} \mathrm{C}, 14.2^{\circ} \mathrm{API}$ and biodegradation level 5-6 according to Peters and Moldowan (26), named reservoir two), and one presenting moderate level of biodegradation produced from the Macaé Formation (2,006-2,015 m deep, reservoir temperature about $71^{\circ} \mathrm{C}, 19.3^{\circ} \mathrm{API}$ and biodegradation level 3-4 according to Peters and Moldowan (26), named reservoir three). The characteristics of the study area are described elsewhere (32). The oil samples from the three distinct reservoirs were collected in triplicate, using 21 sterile Schott bottles. Formation water, collected together with the oil sample, was obtained only from reservoir one. The bottles were completely filled with the water/oil samples, hermetically closed and kept on ice during transportation to the laboratory, where they were maintained at $4^{\circ} \mathrm{C}$ for subsequent molecular analyses.

\section{DNA extraction from water and oil samples}

Total genomic DNA was extracted from environmental samples using the product QIAamp DNA Stool Mini Kit (Qiagen Inc., Valencia, CA, USA), according to Tanaka et al. (37) with minor modifications, which included the use of two grams of initial sample amount and $30 \mathrm{ml}$ of elution buffer for final elution of total DNA. For DNA extraction from the formation water, the bottles were positioned upside down in a way that the water was in contact with the bottle lid. The lid was provided with a small hole and an inner silicone seal, and the water samples were collected using a needle attached to a syringe. For oil DNA extraction, the bottles were maintained in the upright position. In this way, the oil was kept in the upper part of the bottle and pipetted under continuous nitrogen flow, in order to avoid the presence of oxygen and consequent alterations in the original community composition. Due to oil viscosity, the bottles were pre-heated at $80^{\circ} \mathrm{C}$ for $30 \mathrm{~min}$ before oil collection. DNA extraction results were checked on $0.8 \%$ agarose gels stained with 2.5X Sybr Green I (Molecular Probes) for one hour.

\section{PCR of 16S rDNA sequences}

PCR amplification of 16S rDNA fragments was done by using the bacterial primer set U968f and L1401r (13). The reactions (25 $\mathrm{ml}$ ) contained $5 \mathrm{ml}$ of total DNA, $2 \mathrm{U}$ Taq polymerase (GE Health Care), $0.2 \mathrm{mmol} \mathrm{l}^{-1} \mathrm{dNTP}$ mix, and $0.4 \mathrm{mmol} \mathrm{l}^{-1}$ of each primer, in $1 \mathrm{X}$ Taq buffer containing $1.5 \mathrm{mM} \mathrm{MgCl}_{2}$. The PCR amplifications were done using an initial denaturation step at $94^{\circ} \mathrm{C}$ for $5 \mathrm{~min}$, followed by 10 cycles of $1 \mathrm{~min}$ at $94^{\circ} \mathrm{C}, 30 \mathrm{~s}$ at $58^{\circ} \mathrm{C}$, decreasing $0.5^{\circ} \mathrm{C}$ each cycle, and $2 \mathrm{~min}$ at $72^{\circ} \mathrm{C}$, other 25 cycles of $1 \mathrm{~min}$ at $94^{\circ} \mathrm{C}, 30 \mathrm{~s}$ at $53^{\circ} \mathrm{C}$, and $2 \mathrm{~min}$ at $72^{\circ} \mathrm{C}$ and a final extension at $72^{\circ} \mathrm{C}$ for $2 \mathrm{~min}$, in a iCycler System (BioRad). A second PCR reaction was performed using $5 \mathrm{ml}$ of the first PCR products as template and the same primers (GC clamp attached to the primer U968f) and conditions specified for the first PCR reaction. The PCR reactions were performed in duplicate, in order to obtain adequate DNA amount for DGGE electrophoresis. For cloning purposes, the second PCR reaction was performed using the forward primer (U968f) without the GC clamp. Amplification products were checked in $1.2 \%$ agarose gels stained with ethidium bromide $\left(0.1 \mathrm{mg} \mathrm{ml}^{-1}\right)$ and stored at $-20^{\circ} \mathrm{C}$ for subsequent cloning or DGGE analyses.

\section{DGGE analyses}

DGGE analyses were performed using oil samples from the three distinct reservoirs and the formation water from reservoir one. DGGE was carried out using the DCode System (BioRad), according to the manufacturer instructions, using a linear denaturing gradient of urea and formamide ranging from 50 to $70 \%$ (100\% denaturant corresponding to $7 \mathrm{M}$ urea and $40 \%$ (v/ v) deionized formamide). Gels were run at $50 \mathrm{~V}$ and $60^{\circ} \mathrm{C}$ for $14 \mathrm{~h}$ in 0.5 X TAE buffer. Forty microliters (about $400 \mathrm{ng}$ ) of PCR products of each environmental sample were loaded on the 
DGGE gel. In the DGGE analysis of individual clones, $20 \mathrm{ml}$ of PCR products were used. Gels were stained and documented as described by Rosado et al. (30).

\section{S rDNA cloning and sequencing}

PCR products $(2-3 \mathrm{ml})$ obtained for the water and oil samples from reservoir one were directly cloned into the pGEM-T vector (pGEM-T Vector System Kit, Promega), according to manufacturer's instructions. Plasmid DNA was isolated from the clones and subjected to PCR reactions using the primer set U968f-GC and L1401r for subsequent DGGE electrophoresis. The PCR and DGGE conditions followed those described above. PCR products generated from the environmental samples were also loaded on the DGGE gel to allow band migration comparison with the clone bands. Plasmids were subsequently purified using GFX $^{\mathrm{TM}}$ PCR-DNA and gel band purification kit (GE Health Care) and submitted to automated sequencing in a MegaBace DNA Analysis System (GE Health Care) using the DYEnamic ET Dye Terminator Cycle Sequencing Kit (GE Health Care) and 3.2 pmoles of each M13 forward (5'-CGC CAG GGT TTT CCCAGT CAC GAC - $3^{\prime}$ ) and M13 reverse (5'-TTT CAC ACA GGAAAC AGC TAT GAC - $3^{\prime}$ ) primers. Sequences obtained from the clone libraries were deposited at the Genbank database under the accession numbers DQ242019 to DQ242037, and DQ317390 to DQ317391 (Table 1).

\section{Phylogenetic analysis}

Sequences of $16 \mathrm{~S}$ rDNA fragments generated in this study were compared with reference sequences that showed high similarity values in the BLAST-N searches and an additional outgroup sequence, all recovered from GenBank. The sequences were aligned using the CLUSTAL X program (38) and analyzed using the PAUP software (version 4.0 beta 10) (35). Evolutionary distances were calculated using the Kimura $2 p$ DNA substitution model (16) and phylogenetic reconstruction (Figure 3) was done using the neighbor-joining algorithm (31), with bootstrap values calculated from 1,000 replicate runs.

\section{RESULTS AND DISCUSSION}

The DNA extraction protocol used (37) did not yield enough amount of DNA that could be visualized on agarose gels stained with Sybr Green I. Positive results of DNA extraction were observed on agarose gels when pure cultures were used as positive controls. Despite of that, $5 \mathrm{ml}$ of the DNA solution obtained from environmental samples were used in the first PCR reaction, as described in the text. However, only after the second PCR reaction, 16S rDNA products of the expected size could be visualized on agarose gels (data not shown). It is important to note that PCR reactions without DNA, used as negative controls, did not yield any positive signal of amplification after the second PCR round.
Bacterial diversity was first compared between formation water and oil samples from reservoir one (non-biodegraded). Similar DGGE profiles were observed between both samples, except for three bands observed in one replicate of water sample (arrows, replicate 1.5, Fig. 1) and one faint band present in one replicate of the oil sample (arrow, replicate 1.5, Fig. 1). Although these differences may seem relevant for patterns presenting so few bands, they were not reproducible among the replicates. In that context, the bacterial diversity was considered very similar between water and oil samples of the non-biodegraded reservoir. It may be worth to note that the variability observed among some of the replicates may have been related to the presence of low numbers of specific targets in the samples, as DNA template number can affect the amplification in complex template mixtures (5). Specifically, targets of low prevalence may amplify in a nonrepresentative manner as a result of erratic amplification in the first cycles; yielding non-reproducible patterns (13).

The diversity of the dominant bacterial phylotypes, represented by the distinct rDNA $16 \mathrm{~S}$ fragments separated on DGGE, was as well similar among the oil samples originated from the three reservoirs presenting distinct levels of biodegradation.
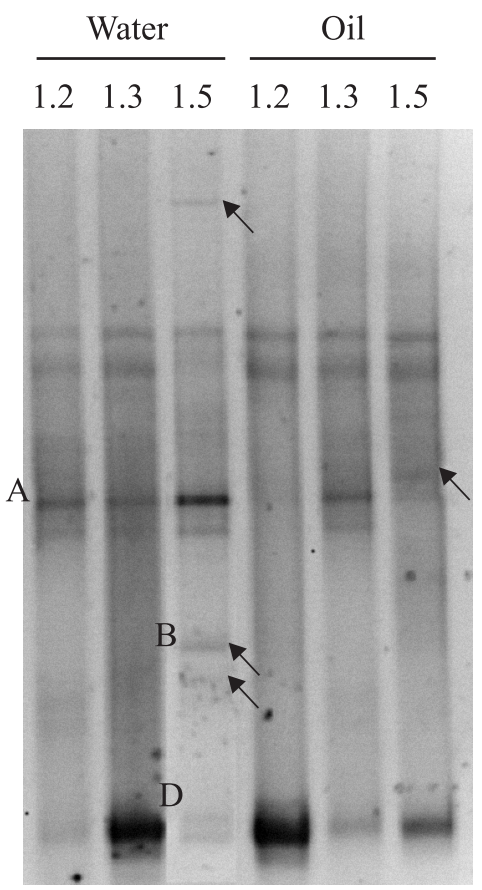

Figure 1. DGGE of 16S rDNA fragments amplified from three replicates $(1.2,1.3$ and 1.5) of formation water and oil samples from petroleum reservoir one (non-biodegraded). Arrows indicate bands of particular occurrence, and letters indicate bands of environmental profile that presented migration behavior similar to that of clones A, B and D, cloned from water sample DNA. 
Bands characterizing one specific reservoir were not observed. However, some bands were shown to be of particular occurrence, being non-reproducible among the replicates (arrows, Fig. 2). The similar band patterns were not expected, since specific microbial populations may be related to oil biodegradation $(1,17,19)$, and that should be reflected in the DGGE profiles representing the main components of the community. However, it could be speculated that the different reservoirs under study have similar microbial profiles for those organisms that were amplified in the PCR reaction, as a consequence of selection by the unique characteristics of the environment and/or because of the inferred common source of the studied oils, as demonstrated by the bulk, isotopic and molecular analyses (MPLC, GC, biomarkers, $\left.\mathrm{d}^{13} \mathrm{C}\right)(12,21)$. This hypothesis is corroborated by the results obtained from a parallel study carried out by the authors employing 16S rDNA libraries assembly of the non-biodegraded (reservoir one) and the highly biodegraded (reservoir two) oil samples, which revealed no significant differences between the bacterial communities compared using statistical indices (32).

In order to identify the predominant components in the bacterial communities of formation water and oil samples, cloning and sequencing of $16 \mathrm{~S}$ rDNA PCR products yielded using primers U968f and L1401r was carried out with samples from

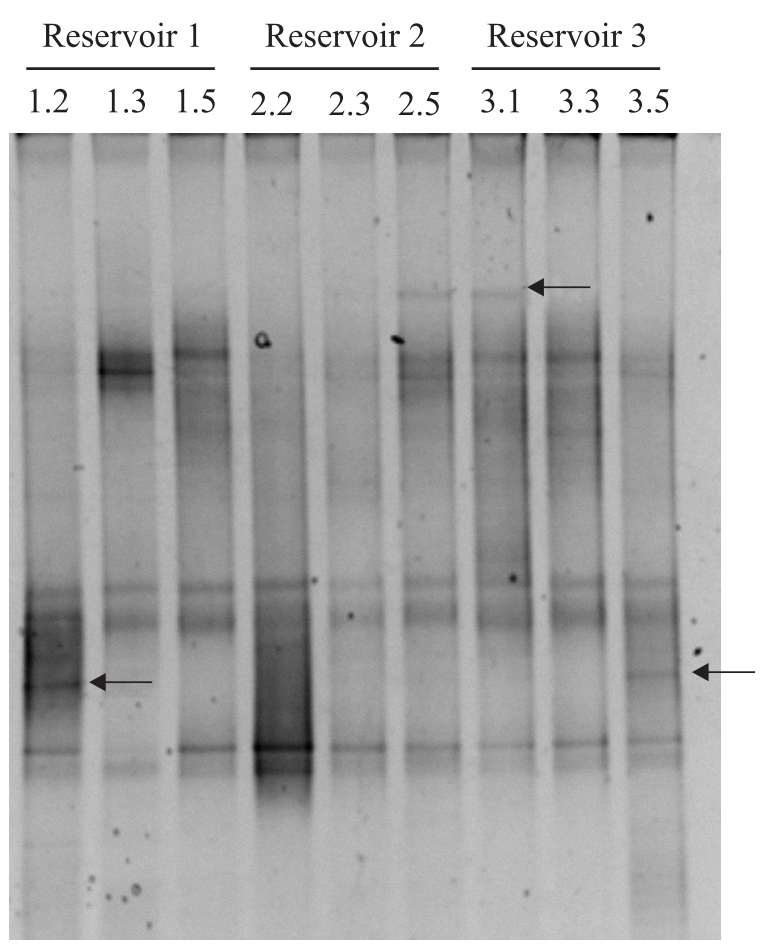

Figure 2. DGGE of 16S rDNA fragments amplified from three replicates of oil samples from petroleum reservoirs 1, 2 and 3 . Arrows exemplify bands that are not reproducible among replicates of one sample. reservoir 1. Eleven clones were obtained from water sample, being 10 successfully sequenced. Blast-N analysis of the $16 \mathrm{~S}$ rDNA clone sequences revealed Halanaerobium sp. and Bacillus sp. as the predominant bacterial community components of water sample from reservoir one (Table 1). Migration behavior of clones A, B and D corresponded to that of bands visualized in environmental profile (Fig. 1, bands named $\mathrm{A}, \mathrm{B}$ and $\mathrm{D})$. Clones $\mathrm{E}, \mathrm{F}, \mathrm{J}$ and $\mathrm{K}$ co-migrated with one of the bands indicated on the DGGE gel (A, B or D, Fig. 1). Bands corresponding to clones $\mathrm{G}, \mathrm{H}$ and I (Table 1) were not visualized in the DGGE profile of the environmental sample.

Fifteen clones were obtained from oil sample of reservoir one, being 11 successfully sequenced. Blast-N analysis revealed the presence of Acidithiobacillus ferrooxidans, Alicyclobacillus acidoterrestris, Rhodococcus sp. and Streptomyces sp., additionally to Halanaerobium sp. and Bacillus sp. (Table 1). Some clones presented gel migration and phylogenetic affiliation consistent to clones from water sample, such as clones 3 (same position as clone 4), 8 and 9, which were identical to clone A, and clone 10 , which was identical to clone $\mathrm{D}$ (data not shown). Bands corresponding to clones 2, 5, 6 (same position as clone 7), 11, 12, 13 and 14 were not visualized in the DGGE profile of the oil sample. Unfortunately, sequencing of clones 4, 6, 7 and 15, although repeated three times, was not successful.

Phylogenetic analysis (Fig. 3) illustrates the relationships of the clones with their closest affiliates in the database based on the $16 \mathrm{~S}$ rDNA sequences. Clones A, E, F, G, H, I and K, from water sample, were recovered in a tight cluster related to several Halanaerobium species (98-99\% similarity and $100 \%$ bootstrap value). Clones $\mathrm{B}, \mathrm{J}$ and $\mathrm{D}$ were removed from the phylogenetic tree reconstruction due to low quality sequences. The same was true to clones 5, 9 and 14, from oil sample. The relationship of the oil clones with the above-mentioned organisms is supported by high bootstrap values (Fig. 3).

Although the DGGE results did not reveal major differences in bacterial phylotype diversity among samples, the $16 \mathrm{~S} \mathrm{rDNA}$ cloning and sequencing approach showed a more diverse bacterial community for the oil sample from reservoir one, comparatively to the formation water sample (Table 1; Fig. 3). Obviously, these results may be considered as a first glance on the bacterial diversity present in these petroleum samples, as the numbers of clones analyzed were too low.

We speculate that the discrepant results obtained when using the DGGE and 16S rDNA cloning and sequencing approach are due to the non-representativeness of low abundance DNA templates originated from environmental samples in DGGE profiles after PCR amplification, which are below the detection level of the DGGE technique. These targets of low prevalence may, on the other hand, be ligated into plasmid vectors, due to a high vector:insert ratio, and subsequently identified by clone sequencing. In this study, this could be exemplified by the $16 \mathrm{~S}$ rDNA sequences corresponding to the 
Table 1. Sequence identities of formation water and oil clones from petroleum reservoir one.

\begin{tabular}{cclcc}
\hline Clone & $\begin{array}{c}\text { Accession } \\
\text { number }\end{array}$ & \multicolumn{1}{c}{ Best match in Blast analysis } & $\begin{array}{c}\text { Identity scores } \\
\text { (\% similarity) }\end{array}$ & Sample \\
\hline A & DQ241019 & Halanaerobium acetethylicum / H. congolense / H. saccharolyticum & 98 & Water \\
B & DQ241025 & Halanaerobium saccharolyticum / H. acetethylicum / H. kushnerii & 98 & Water \\
D & DQ241027 & Bacillus pumilus / Bacillus sp. ROO40B & 95 & Water \\
E & DQ241020 & Halanaerobium acetethylicum / H. congolense & 98 & Water \\
F & DQ241021 & Halanaerobium acetethylicum & 99 & Water \\
G & DQ241022 & Halanaerobium acetethylicum & 99 & Water \\
H & DQ241023 & Halanaerobium acetethylicum / H. congolense / H. saccharolyticum & 98 & Water \\
I & DQ241024 & Halanaerobium acetethylicum / H. congolense & 98 & Water \\
J & DQ241026 & Halanaerobium saccharolyticum / H. acetethylicum / & 98 & Water \\
K & DQ241028 & Halanaerobium acetethylicum / H. congolense & 98 & Water \\
1 & DQ241029 & Acidithiobacillus ferroxidans & 99 & Oil \\
2 & DQ241030 & Halanaerobium sp. KT-2/3-3/H. acetoethylicum / H. congolense / & 95 & Oil \\
3 & DQ241031 & Halanaerobium sp. KT-2/3-3/H. acetoethylicum & 98 & Oil \\
5 & DQ241032 & Alicyclobacillus acidoterrestris ATCC 49025 & 97 & Oil \\
8 & DQ241033 & Halanaerobium sp. KT-2/3-3/ H. acetoethylicum / H. congolense / & 97 & Oil \\
9 & DQ317391 & Halanaerobium sp. KT-2/3-3/ H. acetoethylicum / & 98 & Oil \\
10 & DQ241034 & Bacillus pumilus / Bacillus sp. MI-33a2 / Bacillus sp. ROO40B & 99 & Oil \\
11 & DQ241035 & Streptomyces griseofuscus / Streptomyces nodosus & 98 & Oil \\
12 & DQ241036 & Rhodococcus wratislaviensis / Rhodococcus opacus & 99 & Oil \\
13 & DQ241037 & Rhodococcus wratislaviensis / Rhodococcus opacus & 99 & Oil \\
14 & DQ317390 & Rhodococcus wratislaviensis / Rhodococcus opacus & 99 & Oil \\
\hline
\end{tabular}

organisms Rhodococcus (clones 12, 13 and 14), Alicyclobacillus acidoterrestris (clone 5) and Streptomyces (clone 11), which were not detected in the oil DGGE profile but were detected by the cloning approach, revealing a more diverse community for the oil sample compared to the water sample. Low abundance of microorganisms in deep subsurface environments has been reported elsewhere (25).

Except for Alicyclobacillus acidoterrestris, previous literature confirm that all the organisms found in the formation water and oil samples could be undoubted components of the petroleum reservoir bacterial communities analyzed $(15,28)$, although the probability of sample contamination by exogenous microorganisms originated from drilling techniques or the formation of biofilms in the pipelines can not be definitely excluded.

Members from Bacillus have been associated with petroleum and hydrocarbon degradation in many others studies $(30,45)$. Toledo et al. (39) have shown that several B. pumilus strains, isolated from crude oil waste, could use aromatic hydrocarbons as the sole carbon and energy source, and remove them at high rates from the culture medium. Some Bacillus licheniformis strains, isolated from the rock of a virgin oil reservoir located in a deep-water production basin in Brazil, were able to degrade crude oil and to grow in the presence of carbazole, $n$-hexadecane and polyalphaolefin (PAO) as the only carbon sources (6). Furthermore, the authors could detect PCR products when the DNA of these Bacillus strains were screened for the presence of catabolic genes encoding alkane monooxygenase, catechol 1,2-dioxygenase, and/or catechol 2,3-dioxygenase, suggesting that they may have some degrading activity in the subsurface from which they were isolated.

Additionally, Rhodococcus spp., including R. opacus and $R$. wratislaviensis, as well as Streptomyces-related organisms, are commonly found in oil-contaminated environments and have already been reported as degraders of petroleum derivatives $(2,9,10,27,32)$.

Alicyclobacillus is a thermo-resistant and acidophilic microbial group, generally isolated from soil, fruits and acidthermo-processed food (43). The finding of this bacterium in the oil sample from reservoir one was corroborated by complementary experiments conducted in our laboratories, which led to the isolation and identification of strains of Alicyclobacillus acidoterrestris from the same oil samples described in this work (29). 


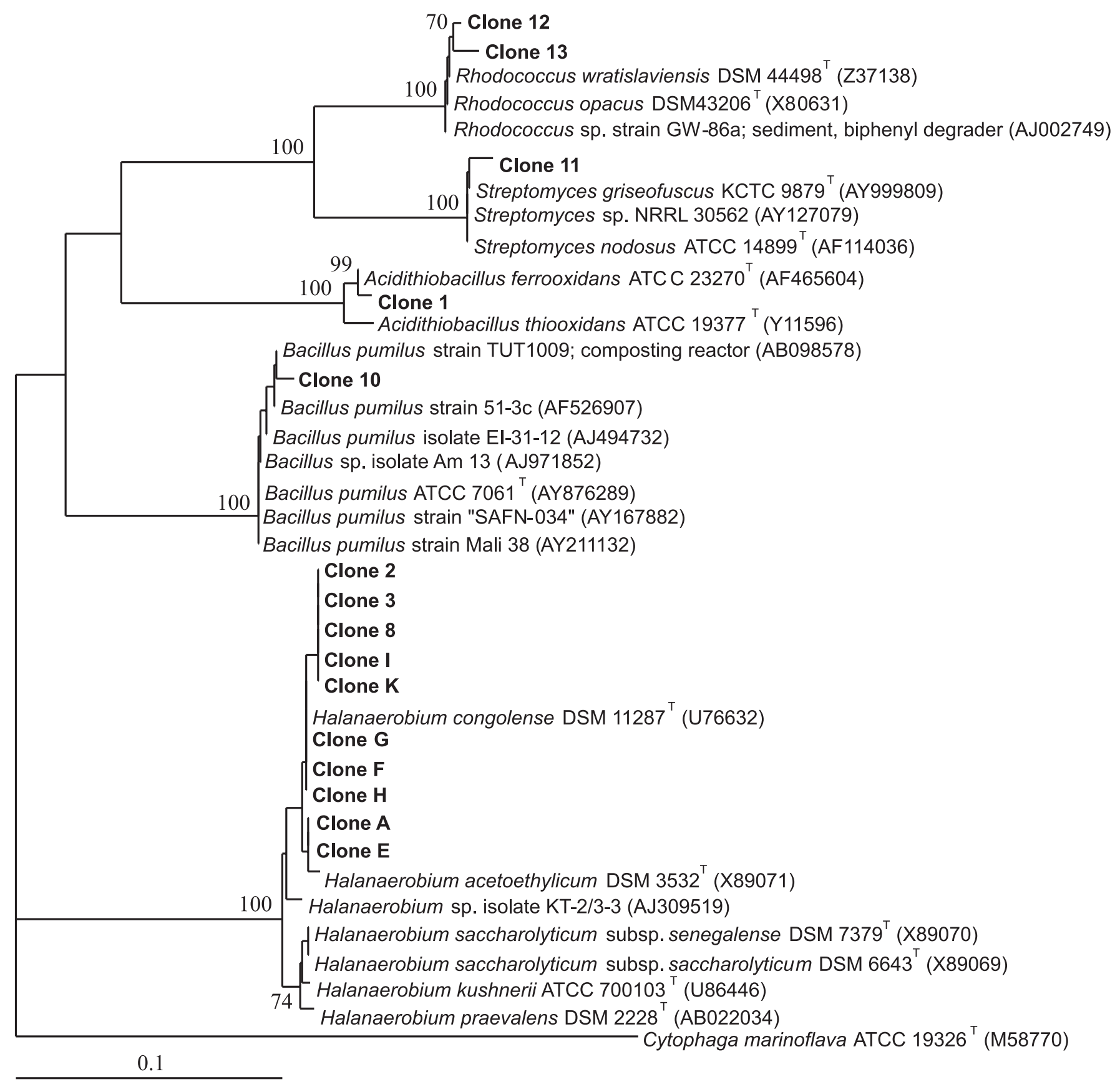

Figure 3. Phylogenetic analysis based on partial 16S rDNA sequences of clones derived from water and oil samples from reservoir one and related microorganisms using the Kimura $2 p$ evolutionary model and the neighbor joining method for tree reconstruction. Bootstrap values (1,000 replicate runs, shown as \%) greater than $70 \%$ are listed. See Table 1 for clone designation. GenBank accession numbers are listed after species names. Cytophaga marinoflava ATCC 19326 ${ }^{\mathrm{T}}$ (M58770) was used as outgroup.

The combined results obtained in this work allowed a rapid evaluation of the bacterial diversity present in the formation water and oil samples under study, although we speculate that an optimization of the DNA extraction protocol, yielding a greater amount of environmental DNA and higher quality PCR products, may allow a thorough and effective use of the DGGE technique in the monitoring of bacterial populations in biodegraded reservoir environments. In that sense, other DNA extraction 
protocols shall be tested and adapted for the analysis of such water and oil samples, where the abundance of microbial groups is very low. Yoshida et al. (44) have recently used 2,2,4trimethylpentane (isooctane) to treat oil samples, associated with Fast DNA SPIN kit (Bio101; Carlsbad, CA, USA) for DNA extraction, and reported the amplification of bacterial 16S rDNA in the first round of PCR amplification. Additionally, cultivationbased experiments are being conducted by our research group aiming at the isolation of bacterial species from the same samples and characterization of their potential to degrade petroleum biomarkers using individual cultures as well as consortia. All the data gathered together will contribute to the knowledge of biodegradation processes that take place in oil reservoir environments.

In conclusion, the results of this study revealed the presence of some taxonomic groups, such as Rhodococcus sp., Acidithiobacillus ferrooxidans and Alicyclobacillus acidoterrestris, not previously found in the same samples when using an extensive 16S rDNA library construction approach (32). This may be due to biases inherent to the PCR technique (34), what reinforces the idea that PCR-based methods cannot account for all organisms from a given sample, and a polyphasic approach is needed when a more comprehensive assessment of microbial diversity is sought.

\section{ACKNOWLEDGEMENTS}

L.D.S. and K.C.M.S. were supported by grants from Brazilian National Research Council (CNPq) in the CTPetro Program. We also thank Petrobras and FINEP for financial support.

\section{RESUMO}

\section{Caracterização da diversidade bacteriana em amostras de petróleo provenientes de reservatórios brasileiros}

Este estudo teve como objetivo comparar as comunidades bacterianas de amostras de água de formação e de óleo de reservatórios de petróleo brasileiros com diferentes graus de biodegradação usando a técnica de PCR-DGGE. O DNA ambiental foi isolado e empregado em reações de PCR com primers bacterianos, com subseqüente separação dos fragmentos de DNAr 16S em DGGE. Os produtos de PCR foram também clonados e seqüenciados, visando à afiliação taxonômica dos membros da comunidade. Os fingerprints obtidos permitiram a comparação direta entre as comunidades bacterianas das amostras de óleo com diferentes graus de biodegradação, assim como entre as comunidades da água de formação e do óleo do reservatório não biodegradado. Perfis de DGGE muito similares foram observados para todas as amostras, e a diversidade dos filotipos bacterianos predominantes mostrou-se baixa. Os resultados de clonagem e seqüenciamento revelaram diferenças mais significativas entre as amostras de água de formação e de óleo do reservatório não biodegradado. Bacillus sp. e Halanaerobium sp. mostraram-se os componentes predominantes da comunidade bacteriana da presente na amostra de água de formação, ao passo que a amostra de óleo incluiu também Alicyclobacillus acidoterrestris, Rhodococcus sp., Streptomyces sp. e Acidithiobacillus ferrooxidans. A técnica de PCR-DGGE, combinada com clonagem e seqüenciamento dos produtos de PCR, revelou a presença de grupos taxonômicos não encontrados anteriormente nestas amostras quando métodos baseados em cultivo e na construção de bibliotecas de genes RNAr 16S foram utilizados, evidenciando a necessidade de um estudo polifásico a fim de contribuir para o conhecimento da diversidade microbiana em ambientes extremos como reservatórios de petróleo.

Palavras-chave: Diversidade bacteriana, comunidade de DNA, análise independente de cultivo, petróleo, 16S rDNA

\section{REFERENCES}

1. Atanga, H.I. (1996). Microbial profile of crude oil in storage tanks. Environ. Monit. Assess., 41, 301-308.

2. Bachoon, D.S.; Araujo, R.; Molina, M.; Hodson, R.E. (2001). Microbial community dynamics and evaluation of bioremediation strategies in oil-impacted salt marsh sediment microcosms. J. Ind. Microbiol. Biotechnol., 27, 72-79.

3. Bastin, E. (1926). Microorganisms in oil fields. Science, 63, 21-24.

4. Bonch-Osmolovskaya, E.A.; Miroshnichenko, M.L.; Lebedinsky, A.V.; Chernyh, N.A.; Nazina, T.N.; Ivoilov, V.S.; Belyaev, S.S.; Boulygina, E.S.; Lysov, Y.P.; Perov, A.N.; Mirzabekov, A.D.; Hippe, H.; Stackebrandt, E.; L'Haridon, S.; Jeanthon, C. (2003). Radioisotopic, culture-based, and oligonucleotide microchip analyses of thermophilic microbial communities in a continental high-temperature petroleum reservoir. Appl. Environ. Microbiol., 69, 6143-51.

5. Chandler, D.P.; Fredrickson, J.K.; Brockman, F.J. (1997). Effect of PCR template concentration on the composition and distribution of total community 16S rDNA clone libraries. Mol. Ecol., 6, 475-482.

6. Cunha, C.D.; Rosado, A.S.; Sebastián, G.V.; Seldin, L.; Weid, I. (2006) Oil biodegradation by Bacillus strains isolated from the rock of an oil reservoir located in a deep-water production basin in Brazil. Appl. Microbiol. Biotechnol., 73, 949-959.

7. Davey, M.E.; Word, W.A.; Key, R., Nakamura, K.; Stahl, D.A. (1993) Isolation of three species of Geotoga and Petrotoga: two new genera, representing a new lineage in the bacterial line. System. Appl. Microbiol., 16, 191-200.

8. DeLong, E.F. (1992). Archaea in coastal marine environments. Proc. Natl. Acad. Sci. USA, 89, 5685-5689.

9. Erdlenbruch, B.N.; Kelly, D.P.; Murrell, J.C. (2001). Alkanesulfonate degradation by novel strains of Achromobacter xylosoxidans, Tsukamurella wratislaviensis and Rhodococcus sp., and evidence for an ethanesulfonate monooxygenase in A. xylosoxidans strain AE4 Arch. Microbiol., 176, 406-414.

10. Gauthier, E.; Deziel, E.; Villemur, R.; Juteau, P.; Lepine, F.; Beaudet, R. (2003). Initial characterization of new bacteria degrading highmolecular weight polycyclic aromatic hydrocarbons isolated from a 2-year enrichment in a two-liquid-phase culture system. J. Appl. Microbiol., 94, 301-311. 
11. Greene, A.C.; Patel, B.K.; Sheehy, A.J. (1997). Deferribacter thermophilus gen. nov., sp. nov., a novel thermophilic manganeseand iron-reducing bacterium isolated from a petroleum reservoir. Inter. J. System. Bacteriol., 47, 505-509.

12. Guardado, L.R.; Mello, M.R.; Spadini, A.R.; Brandão, J.S.L. (2000). Petroleum system of the Campos Basin, Brazil. In: Mello, M.R., Katz, B.J. (eds). Petroleum Systems of South Atlantic margins. AAPG Memoir 73, p. 317-324.

13. Heuer, H.; Krsek, M.; Baker, P.; Smalla, K.; Wellington, E.M.H. (1997). Analysis of actinomycete communities by specific amplification of genes encoding $16 \mathrm{~S}$ rRNA and gel-electrophoretic separation in denaturing gradients. Appl. Environ. Microbiol., 63, 3233-3241.

14. Hugenholtz, P.; Goebel, B.M.; Pace, N.R. (1998). Impact of cultureindependent studies on the emerging phylogenetic view of bacterial diversity. J. Bacteriol., 180, 4765-4774.

15. Kelly, D.P.; Wood, A.P. (2000). Reclassification of some species of Thiobacillus to the newly designated genera Acidithiobacillus gen. nov., Halothiobacillus gen. nov. and Thermithiobacillus gen. nov. Inter. J. System. Evol. Microbiol., 50, 511-6.

16. Kimura, M. (1980). A simple method for estimating evolutionary rate of base substitutions through comparative studies of nucleotide sequences. J. Mol. Evol., 16, 111-120.

17. Leahy, J.G.; Colwell, R.R. (1990). Microbial degradation of hydrocarbons in the environment. Microbiol. Rev., 54, 305-315.

18. Lien, T.; Madsen, M.; Rainey, F.A.; Birkeland, N.K. (1998). Petrotoga mobilis sp. nov., from a North Sea oil-production well. Inter. J. System. Bacteriol., 48, 1007-13.

19. MacNaughton, S.J.; Stephen, J.R.; Venosa, A.D.; Davis, G.A.; Chang, Y.J.; White, D.C. (1999). Microbial population changes during bioremediation of an experimental oil spill. Appl. Environ. Microbiol., $65,3566-3574$

20. Magot, M.; llivier, B.; Patel, B.K.C. (2000). Microbiology of petroleum reservoirs. Ant. Leeuw., 77, 103-116.

21. Mohiak, W.U.; Mello, M.R.; Karner, G.D.; Dewey, J.F.; Maxwell, J.R. (1989). Structural and Stratigraphic Evolution of the Campos Basin, Offshore Brazil: Chapter 38: Analogs, M 46: Extensional Tectonics and Stratigraphy of the North Atlantic Margins, Pages 577-598, AAPG Memoir.

22. Muyzer, G.; Hottentrager, S.; Teske, A.; Wawer, C. (1995). Denaturing gradient gel electrophoresis of PCR-amplified 16S rDNA - a new molecular approach to analyse the genetic diversity of mixed microbial communities. In: Molecular microbial ecology manual. Akkermans, A.D.L., van Elsas, J.D., de Bruijn, F.J. (eds). section 3.4.4, pp. 1-23. Dordrecht, The Netherlands: Kluwer Academic Publishers.

23. Orphan, V.J.; Taylor, L.T.; Hafenbradl, D.; Delong, E.F. (2000). Culture-dependent and culture-independent characterization of microbial assemblage associated with high temperature petroleum reservoirs. Appl. Environ. Microbiol., 66, 700-711.

24. Pace, N.R. (1997). A molecular view of the microbial diversity and the biosphere. Science, 276, 734-740.

25. Parkes, R.J.; Cragg, B.A.; Bale, S.J.; Getlifff, J.M.; Goodman, K.P.; Rochelle, A.; Fry, J.C.; Weightman, A.J.; Harvey, S.M. (1994). Deep bacterial biosphere in Pacific Ocean sediments. Nature, 371, 410-413.

26. Peters, K.E.; Moldowan, J.M. (1993). The Biomarkers Guide. Prentice-Hall, New York, pp. 363.

27. Radwan, S.S.; Barabas, G.; Sorkhoh, N.A.; Damjanovich, S.; Szabo, I.; Szollosi, J.; Matko, J.; Penyige, A.; Hirano, T.; Szabo, I.M. (1998). Hydrocarbon uptake by Streptomyces. FEMS Microbiol. Lett., 169, 87-94.

28. Ravot, G.; Magot, M.; Ollivier, B.; Patel, B.K.; Ageron, E.; Grimont, P.A.; Thomas, P.; Garcia, J.L. (1997). Haloanaerobium congolense sp. nov., an anaerobic, moderately halophilic, thiosulfate- and sulfurreducing bacterium from an African oil field. FEMS Microbiol. Lett., $147,81-88$
29. Rodrigues, D.C.; Pantaroto, S.; Alves, P.B.; Nascimento, L.R.; Abreu Filho, B.A.; Oliveira, V.M.; Manfio, G.P.; Santos Neto, E.V.; Marsaioli, A.J. (2005). Relationship between cyclohexyl-alkanoic acids and the acidothermophilic bacterium Alicyclobacillus spp.: Evidence from Brazilian Oils. Org. Geochem., 36, 1443-1453.

30. Rosado, A.S.; Duarte, G.F.; Seldin, L.; van Elsas, J.D. (1998). Genetic diversity of nifH gene sequences in Paenibacillus azotofixans strains and soil samples analysed by denaturing gradient gel electrophoresis of PCR-amplified gene fragments. Appl. Environ. Microbiol., 64, 2770-2779.

31. Saitou, N.; Nei, M. (1987). The neighbor-joining method: a new method for reconstructing phylogenetic trees. Mol. Biol. Evol., 4, 406-425.

32. Sette, L.D.; Simioni, K.C.M.; Vasconcelos, S.P.; Dussán, L.J.; Marsaioli, A.J.; Santos Neto, E.V.; Oliveira, V.M. (2006), Analysis of composition of bacterial communities in oil reservoirs from a southern offshore Brazilian basin. Ant. Leeuw., 91, 253-266.

33. Stetter, K.O.; Huber, R.; Bloechl, E.; Kurr, M.; Eden, R.D.; Fiedler, M.; Cash, H.; Vance, I. (1993). Hyperthermophilic archaea are thriving in deep North Sea and Alaskan oil reservoirs. Nature, 365, 743-745.

34. Suzuki, M.T.; Giovannoni, S.J. (1996). Bias caused by template annealing in the amplification of mixtures of $16 \mathrm{~S}$ rRNA genes by PCR. Appl. Environ. Microbiol., 62, 625-630.

35. Swofford, D.L. (2000). PAUP*. Phylogenetic Analysis Using Parsimony (*and Other Methods). Sinauer Associates, Sunderland, MA.

36. Takami, H.; Inoue, A.; Fuji, F.; Horikoshi, K. (1997). Microbial flora in the deepest sea mud of the Mariana Trench. FEMS Microbiol. Lett., 152, 279-85.

37. Tanaka, Y.; Sogabe, M.; Okumura, K.; Kurane, R. (2002). A highly selective direct method of detecting sulphate-reducing bacteria in crude oil. Lett. Appl. Microbiol., 35, 242-246.

38. Thompson, J.D.; Gibson, T.J.; Plewniak, F.; Jeanmougin, F.; Higgins, D.G. (1997). The ClustalX windows interface: flexible strategies for multiple sequence alignment aided by quality analysis tools. Nucleic Acids Res., 24, 4876-4882.

39. Toledo, F.L.; Calvo, C.; Rodelas, B.; González-López, J. (2006). Selection and identification of bacteria isolated from waste crude oil with polycyclic aromatic hydrocarbons removal capacities. System. Appl. Microbiol., 29 (3), 244-252.

40. Van Elsas, J.D.; Smalla, K.; Tebbe, C.C. (2000). Extraction and analysis of microbial community nucleic acids from environmental matrices. In: Jansson, J.K.; van Elsas, J.D.; Bailey, M.J. (eds), Tracking Genetically-Engineered Microorganisms. pp. 29-52. Landes Bioscience, Georgetown, Texas, USA.

41. Van Hamme, J.D.; Singh, A.; Ward, O.P. (2003). Recent advances in petroleum microbiology. Microbiol. Mol. Biol. Rev., 67, 503-549.

42. Voordouw, G.; Armstrong, S.M.; Reimer, M.F.; Fouts, B.; Telang, A.J.; Shen, Y.; Gevertz, D. (1996). Characterization of 16S rRNA genes from oil field microbial communities indicates the presence of a variety of Sulfate-Reducing, Fermentative, and Sulfide-Oxidizing Bacteria. Appl. Environ. Microbiol., 62, 1623-1629.

43. Wisotzkey, J.D.; Jurtshuk, P.Jr.; Fox, G.E.; Deinhard, G.; Poralla, K. (1992). Comparative sequences analyses on the 16S rRNA (rDNA) of Bacillus acidocaldarius, Bacillus acidoterrestris, and Bacillus cycloheptanicus and proposal for creation of a new genus, Alicyclobacillus gen. nov. Inter. J. System. Bacteriol., 42, 263-269.

44. Yoshida, N.; Yagi, K.; Sato, D.; Watanabe, N.; Kuroishi, T.; Nishimoto, K.; Yanagida, A.; Katsuragi, T.; Kanagawa, T.; Kurane, R.; Tani, Y. (2005). Bacterial communities in petroleum oil in stockpiles. $J$. Biosci. Bioeng., 99, 143-149.

45. Zhuang, W.Q.; Tay, J.H.; Maszenan, A.M.; Krumholz, L.R.; Tay, S.T. ( 2003). Importance of Gram-positive naphthalene-degrading bacteria in oil-contaminated tropical marine sediments. Lett. Appl. Microbiol., 36 (4), 251-7. 